\title{
Changes in quality of fried rice with crab meat depending on the storage period and temperature
}

\author{
Ji Hee Jung ${ }^{1}$, Ji Hoon $\mathrm{Lim}^{1}$, Dong Soo Kim${ }^{1}$, Young Myoung Kim², Byoung Mok Kim ${ }^{1 *}$ \\ ${ }^{1}$ Korea Food Research Institute, Seongnam 463-746, Korea \\ ${ }^{2}$ Gi-Jang Mulsan Co. Ltd., Busan 619-911, Korea
}

\section{저장기간 및 저장온도에 따른 꽃게풍미 볶음밥의 품질변화}

\author{
정지희 ${ }^{1} \cdot$ 임지훈 $^{1} \cdot$ 김동수 ${ }^{1} \cdot$ 김영명 $^{2} \cdot$ 김병목 $^{*}$ \\ ${ }^{1}$ 한국식품연구원, ${ }^{2}$ 기장물산( 주)
}

\begin{abstract}
The edible crab is among the rich resources that can be used as materials for food products, but living crabs and crabs marinated in soy sauce are the only widely utilized materials for food products. For seafood development, research is needed to promote the use of crabs in various products. In this study, the quality changes of fried rice prepared with crab meat, crab emulsion sauce and crab cooker effluent were investigated. The $\mathrm{pH}$ and acidity values did not show any significant difference at $-20^{\circ} \mathrm{C}$. The acidity of the fried rice continuously increased during storage at 4 and $25^{\circ} \mathrm{C}$. The VBN and TBA values of the fried rice stored at 4 and $25^{\circ} \mathrm{C}$ were significantly higher than those of the fried rice stored at $-20^{\circ} \mathrm{C}$ during the storage period. The viable cell count of the fried rice stored at $-20^{\circ} \mathrm{C}$ changed little during the storage period while that of the fried rice stored at 4 and $25^{\circ} \mathrm{C}$ rapidly increased over 2 weeks. For the fried rice stored at $-20^{\circ} \mathrm{C}$, the overall quality did not show significant differences during the storage period. In conclusion, the best storage temperature for both quality and safety was found to be $-20^{\circ} \mathrm{C}$. At such storage temperature, the quality of the stored instant rice using crab meat did not change, and through research the expanding possibilities of using crab materials were confirmed.
\end{abstract}

Key words : crab, shelf life, storage period, quality, fried rice

\section{서 론}

우리나라의 쌀 소비 형태를 보면 전체 쌀 생산 $95 \%$ 이상 이 밥으로 소비되고 있으며, 전통적으로 쌀 가공식품으로 면류, 과자, 주류, 엿류 등이 있다. 일본은 식생활의 간편화, 개별 식사화, 다양화 등을 배경으로 활기있게 발달되고 이 와 관련된 기술개발이 계속 이루어지고 있다. 우리나라에 서는 현재 약 200 개 업체에서 가공쌀밥으로 레토르트밥, 무균포장밥, 냉동밥, 건조쌀밥 등을 생산하고 있다(1). 최근

*Corresponding author. E-mail : bmkim@kfri.re.kr Phone : 82-31-780-9313, Fax : 82-31-780-9192

Received 30 April 2014; Revised 22 August 2014; Accepted 28 October 2014.

Copyright (c) The Korean Society of Food Preservation. All rights reserved.
우리나라는 가족구조 변화로 젊은 층의 1 인 가구가 증가하 고, 여성의 사회참여가 늘어나는 등 환경의 변화에 따라 식생활 소비패턴이 변화하고 있으며, 주식으로는 밥의 이 용률이 가장 높은 것으로 나타났다. 편의성을 부여하는 쌀 가공 식품의 수요 증가 특히, 즉석밥 시장 규모 성장률은 2009년 $10.1 \%$ 에서 2012년 $17.7 \%$ 로 증가하고 있다. 즉석조 리식품 시장은 전통적으로 카레와 짜장 등 덮밥류 제품의 판매액이 높은 비중을 자치하고 있었으나, 최근 식생활 트 렌드를 반영한 다양한 품목의 등장으로 덮밥류의 판매 비중 이 점차 감소하고 있는 추세이다. 기존의 '맛있는' 식품에서 '만들기 어려운' 혹은 '보관이 어려운' 식품들의 상품화가 새로운 트렌드로 부각되고 있다(2). 꽃게는 수심 $10 ~ 50 \mathrm{~m}$ 의 모래바닥에서 서식하고 우리나라에서는 인천지역의 어획 쿼터량이 전체 어획량의 약 $50 \%$ 정도를 차지하는 꽃게과에 속하는 갑각류이고, 우리나라에서 가장 많이 식용되는 게 
중의 하나로서 생산량은 2 만 톤 가량 되며, 육질부가 20 40\%이고, 60 80\%가 껍질로 조성되어 있다(3). 꽃게에 관한 연구로는 게의 육중에 함유되어 있는 유리아미노산 함량(4), 지질흭분(5), 핵산관련물질(6) 등이 있고, 자숙게의 아미노산과 관련화합물 함량 $(7,8)$, 핵산관련물질 및 유기염 기류의 분포(9), 엑스분 중의 정미성분에 대한 관능적 특성 (10), 조미 소재로서의 가치(11) 등에 관한 연구가 있으나, 꽃게를 이용한 가공제품에 관한 연구는 미흡한 실정이다. 꽃게가 현재에는 활게, 간장게장용 소재로 활용하는 것 외 에는 뚜렷한 가공제품화가 이뤄지지 않고 있는데, 꽃게관 련 종사자, 수산식품산업의 발전을 위해서는 꽃게를 이용 한 다양한 제품화 연구가 이뤄져야 할 것으로 사료된다. 본 연구에서는 예비실험을 통해 도출된 다양한 연구결과를 바탕으로 꽃게살, 꽃게 효소분해물 등이 함유된 볶음밥으 로 제조하였고, 유통기한을 설정하고자 저장기간 및 저장 온도에 따른 볶음밥의 품질변화를 조사 분석하였다.

\section{재료 및 방법}

\section{실험재료 및 저장 조건}

본 실험에 사용된 꽃게는 2013년 02월 인천에서 구입한 활게를 실험실로 옮겨와 흐르는 물로 이물질을 제거한 후 꽃게풍미 간장소스, 꽃게살 등을 제조하기 위한 원료로 사 용하였다. 즉, 꽃게풍미 간장소스는 간장, 정제염, 물엿, 마 늘, 생강, 물, 맛술을 혼합한 조미액을 제조하여 꽃게를 침지 한 후 $4^{\circ} \mathrm{C}$ 에서 3 일간 숙성하여 가열한 여과액을 사용하였으 며, 꽃게살은 간이채육장비를 이용하여 활꽃게로부터 살을 분리하여 볶음밥 제조시 원료로 사용하였다. 꽃게풍미 유 화소스는 꽃게풍미 간장소스와 들기름을 8:1 비율로 혼합 한 후 유화제(모노글리세라이드) $1.0 \%$ 를 첨가하여 제조한 후 볶음밥 제조시 부원료로 사용하였다. 그 외 부원료로는 꽃게를 통째로 분쇄한 후 $100^{\circ} \mathrm{C}$ 에서 6 시간동안 자숙한 자숙 액과 자숙잔사를 효소분해하여 얻은 효소분해물을 혼합하 여 제조된 꽃게자숙농축액을 사용하였다. 꽃게풍미 볶음밥 은 쌀 함량 대비 $70 \%$ 의 미반수를 첨가하여 제조한 밥에다 가 꽃게자숙농축액, 꽃게풍미 유화소스를 각각의 조건에 따라 첨가하였고, 볶음밥 제조공정에 따라 볶음밥을 제조 하였으며, 플라스틱 용기에 충진한 후 포장하여 실험용 시 료로 사용하였다(Table 1). 제조된 볶음밥은 $-20,4,25^{\circ} \mathrm{C}$ 에 서 각각 저장한 후 6 주 동안 저장하면서 이화학적, 미생물학 적, 관능적 품질변화를 측정하였다.

\section{일반성분}

수분, 조회분, 조단백질 및 조지방 함량은 $\mathrm{AOAC}(12)$ 방 법에 따라 실시하였다. 즉, 수분은 상압가열건조법을 사용 하였고, $105^{\circ} \mathrm{C}$ 에서 6 시간 건조 후 측정하였다. 조회분은
직접 회화법을 사용하였으며, $600^{\circ} \mathrm{C}$ 에서 4시간 동안 태운 후 측정하였다. 조단백질은 semimicro Kjeldahl법을 사용하 였고, 조지방은 ether로 추출하는 Soxhlet추출법을 사용하 였다. 염도는 Mohr법(13)에 의하여 측정하였다. 탄수화물 함량은 100 에서 수분, 조회분, 조단백질, 조지방을 뺀 함량 을 표시하였고(14), 가식부 $100 \mathrm{~g}$ 에 함유되어 있는 양 $(\mathrm{g})$ 으 로 나타내었다.

Table 1. Ingredients for change in quality of fried rice

\begin{tabular}{lcc}
\hline \multicolumn{1}{c}{ Ingredient } & Composition $(\mathrm{g})$ & $\%$ \\
\hline Rice & 77.0 & 71.3 \\
Crab meat & 1.5 & 1.4 \\
Crab emulsification sauce & 2.5 & 2.3 \\
Crab cooker effluents & 5.5 & 5.1 \\
Egg & 5.3 & 4.9 \\
Onion & 2.0 & 1.8 \\
Carrot & 0.8 & 0.7 \\
Potato & 0.7 & 0.6 \\
Green pumpkin & 2.6 & 2.4 \\
Pea & 5 & 4.6 \\
Cone & 5 & 4.6 \\
Salt & 0.3 & 0.3 \\
Total & 107.9 & 100.0 \\
\hline
\end{tabular}

\section{$\mathrm{pH}$ 및 적정산도 측정}

$\mathrm{pH}$ 는 시료 $10 \mathrm{~g}$ 을 취하여 분쇄한 후 증류수 $40 \mathrm{~mL}$ 과 혼합하여 균질한 다음 $\mathrm{pH}$ meter(SG2-ELK, Mettler Toledo Co., Ltd., Switzerland)를 이용하여 측정하였고, 적정산도는 시료 $10 \mathrm{~g}$ 을 취하여 증류수 $40 \mathrm{~mL}$ 를 넣고 균질화하여 여과 한 여과액 $10 \mathrm{~mL}$ 에 $0.1 \mathrm{~N} \mathrm{NaOH}$ 용액으로 적정하여 lactic acid 함량으로 산출하였다.

산도 $(\%$ 젖산 $)=\frac{0.009008 \times \mathrm{NaOH} \text { 소비량 }(\mathrm{mL}) \times \mathrm{NaOH} \text { 역가 } \times \text { 희석배수 }}{\text { 시료의 부피 }(\mathrm{mL})} \times 100$

TBA(thiobarbituric acid) value

시료 $20 \mathrm{~g}$ 을 취하여 $\quad 4^{\circ} \mathrm{C}$ 로 냉각된 $20 \% \quad \mathrm{TCA}$ (trichloroacetic acid in $2 \mathrm{M}$ phosphoric acid) 용액 $50 \mathrm{~mL}$ 를 넣어 90초간 균질하게 마쇄시켰다. 마쇄액을 증류수로 100 $\mathrm{mL}$ 정용하였고, 정용액 중 $50 \mathrm{~mL}$ 를 Whatman No 1 여과지 (Hyundal Micro Co., Seoul, Korea)로 여과한 후 15,000 ppm 에서 10 분간 원심분리하였다. 원심분리된 상층액만 $5 \mathrm{~mL}$ 취해 syringe filter로 여과하여 시험관으로 옮겨 $5 \mathrm{mM}$ 2-thiobarbituric acid $5 \mathrm{~mL}$ 를 넣어 혼합한 다음 상온 암소에 서 15 시간 방치하였고, 발색된 액을 $530 \mathrm{~nm}$ 에서 흡광도 (Thermo scientific, Fiji, Finland)를 측정하였다(15). 표준곡 
선은 malondialdehyde를 이용하였으며, 시료의 흡광도값에 따라 TBA값으로 환산하여 나타내었다.

휘발성염기질소(VBN, volatile basic nitrogen)

시료 $2 \mathrm{~g}$ 을 증류수 $16 \mathrm{~mL}$ 과 $20 \%$ perchloric acid $2 \mathrm{~mL}$ 을 넣고 균질화한 후 $3,000 \mathrm{rpm}$ 에서 15 분간 원심분리하였고, $0.45 \mu \mathrm{m}$ syringe filter로 여과하였다. 여과액 $1 \mathrm{~mL}$ 과 $50 \%$ $\mathrm{K}_{2} \mathrm{CO}_{3} 1 \mathrm{~mL}$ 를 conway unit 외실에, 내실에는 $10 \%$ 붕산흡수 제를 $1 \mathrm{~mL}$ 가하여 $37^{\circ} \mathrm{C}$ 에서 80 분간 방치하였고 이 후 0.01 $\mathrm{N} \mathrm{NaOH}$ 로 적정하여 함량을 구하였다.

$$
\text { 휘발성염기질소 }(\mathrm{mg} \%)=\frac{0.14 \times(\mathrm{A}-\mathrm{B}) \times \mathrm{NaOH} \text { 역가 } \times \text { 희석배수 }}{\text { 시료의 부피 }(\mathrm{mL})} \times 100
$$

$0.14: 0.01 \mathrm{~N} \mathrm{HCl} 1 \mathrm{~mL}=0.14 \mathrm{mg} \mathrm{VBN}$

$\mathrm{A}$ : 본 실험에 소비된 $0.01 \mathrm{~N} \mathrm{HCl}$ 의 소비량 $(\mathrm{mL})$

$\mathrm{B}$ : 바탕 실험에 소비된 $0.01 \mathrm{~N} \mathrm{HCl}$ 의 소비량 $(\mathrm{mL})$

미생물

총균수는 plate count agar(Difco, Detroit, MI, USA)를 사 용하여 $37^{\circ} \mathrm{C}$ 에서 48 시간 배양하여 계측하였다. 즉, 볶음밥 $10 \mathrm{~g}$ 을 취하여 멸균팩(B1348WA, Nasco Co., Ltd, IL, USA) 에 넣은 다음 멸균식염수를 가하여 약 20 초간 흔들어 준 후 단계적으로 희석하여 총균수 측정용 배지에 접종하여 $\log \mathrm{CFU} / \mathrm{g}$ 으로 나타내었다(16).

\section{관능적 기호도}

관능적 기호도는 식품학을 전공하는 대학원생 및 연구원 중 20 대 남자 10 명, 여자 10 명 총 20 인의 관능검사요원을 구성하여 외관, 색, 맛, 향, 조직감 및 전체적 기호도의 6 가지 항목에 대해 9점 평점법(9점: 매우 좋다, 8 7점: 양호, 6 4 점: 보통, 3 2점: 나쁨, 1점: 매우 나쁨)으로 측정하였다. 관능적 품질변화를 조사하기 위해서 실험 당일 각 저장온도 에서 실험중인 볶음밥을 마이크로오븐(MH-681M, LG, Seoul, Korea)으로 2 분간 조리하였고 이를 관능적 품질변화 용 시료로 사용하였다.

\section{유통기한 예측}

볶음밥의 유통기한 예측을 위하여 식품의약품안전처에 서 제공하는 식품의 유통기한 산출 시스템인 visual shelf life simulator for foods(VSLSF)을 이용하여 산출하였다. 이 때 저장온도를 $-20,4,25^{\circ} \mathrm{C}$ 로 각각 나누어 실험하였고, 미생물 결과값을 등록한 후 유통기한 예측값을 구하였다.

\section{통계처리}

본 실험의 결과는 통계분석용 프로그램인 SPSS package program 18.0 을 사용하여 평균과 표준편차를 구하였다. 두 집단 간 평균치 분석은 독립 $\mathrm{T}$ 검정을 수행하여 $\mathrm{p}<0.05$
수준에서 유의차 검증을 실시하였고, 세 집단이상의 평균 치 분석은 one-way ANOVA 방법에 따라 실시하였으며, 평균들간의 유의성 검증은 Duncan's multiple comparison test $(\mathrm{p}<0.05)$ 를 이용하여 검정하였다.

\section{결과 및 고찰}

\section{일반성분}

꽃게풍미 볶음밥의 일반성분을 조사한 결과, 수분함량은 $60.7 \%$, 회분함량은 $1.4 \%$, 단백질 함량은 $6.23 \%$, 지방함량 은 $2.32 \%$, 탄수화물함량은 $29.35 \%$ 인 것으로 나타났다 (Table 2). 일반적으로 유통되고 있는 냉동밥의 수분함량이 58.1 66.0\%로 나타나 본 연구결과와 유사한 것으로 나타났 다. 꽃게풍미 볶음밥의 단백질 함량이 쌀밥의 단백질 함량 (2.6\%)에 비해 높았고, 지방함량 $(0.3 \%)$ 또한 높게 나타난 것은 꽃게풍미 볶음밥 제조시 부원료로 첨가된 재료(꽃게 살, 채소, 유화소스 등)들에 기인된 것으로 사료되었다(17).

Table 2. Proximate composition and salinity of fried rice (unit : \%)

\begin{tabular}{cccccc}
\hline Moisture & Ash & Crude protein & Crude lipid & Carbohydrate & Salinity \\
\hline $60.7 \pm 0.52$ & $1.4 \pm 0.06$ & $6.23 \pm 0.01$ & $2.32 \pm 0.54$ & $29.35 \pm 0.22$ & $1.17 \pm 0.02$ \\
\hline
\end{tabular}

$\mathrm{pH}$

저장 중 $\mathrm{pH}$ 변화는 식품의 부패 현상을 측정하는 지표로 서 유용한 수단이 된다(18). 저장온도 및 저장기간에 따른 꽃게풍미 볶음밥의 $\mathrm{pH}$ 변화를 조사하여 Fig. 1 에 나타내었 다. $-20^{\circ} \mathrm{C}$ 에 저장된 볶음밥의 $\mathrm{pH}$ 는 저장 0 주째 7.74 이었고 저장 6 주에는 7.76 으로 나타나 저장 중 변화가 거의 없는

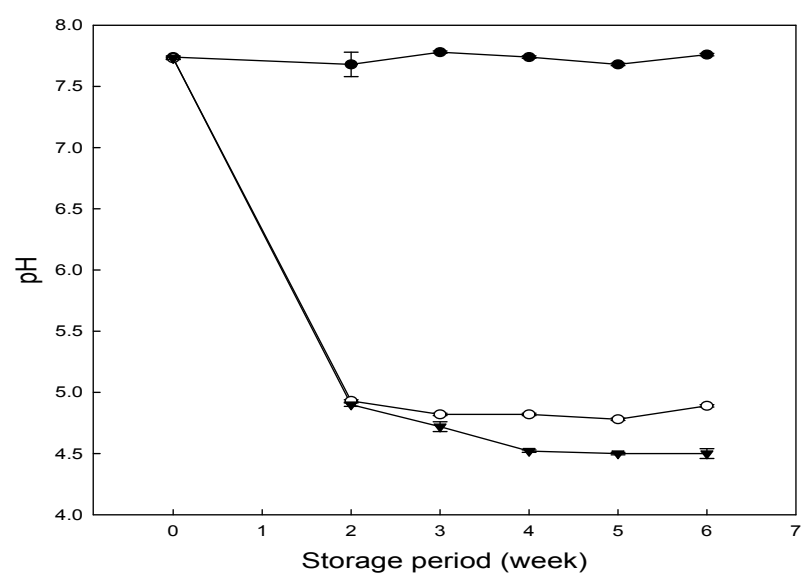

Fig. 1. Changes in the $\mathrm{pH}$ of fried rice depending on the storage period and temperature.

- $-20^{\circ} \mathrm{C} ; \quad 0,4^{\circ} \mathrm{C} ; \boldsymbol{\nabla}, 25^{\circ} \mathrm{C}$. Values are mean $\pm \mathrm{SD}(\mathrm{n}=5)$. 
것으로 나타났다. 반면, $4^{\circ} \mathrm{C}$ 에서 저장된 볶음밥의 $\mathrm{pH}$ 는 저 장 0 주째 7.73 이었으나, 저장 2 주째에는 4.93 으로 급격히 낮아졌고, 저장 6주까지 $\mathrm{pH}$ 4.82 4.89 수준으로 나타났다. $25^{\circ} \mathrm{C}$ 에 저장된 볶음밥의 $\mathrm{pH}$ 는 저장 0 주째 7.73 이었으나, 저장 2 주째에는 4.90 으로 나타났고, 이 후 저장 6 주째까지 4.72 4.50 수준으로 나타났으며, 실험온도 구간 중 저장기 간 동안 가장 낮은 $\mathrm{pH}$ 를 보였다. 즉, $-20^{\circ} \mathrm{C}$ 에서 저장할 경우 $\mathrm{pH}$ 는 저장기간 동안 거의 변화가 없었으나, $4^{\circ} \mathrm{C}$ 와 $25^{\circ} \mathrm{C}$ 에 저장할 경우 볶음밥 원료에 함유된 지방의 산패에 따른 과산화물의 축적이나 단백질 분해에 의한 암모니아 생성 등으로 인하여 저장 중 급격한 $\mathrm{pH}$ 변화를 나타낸 것으로 사료되었다.

\section{적정산도}

저장 중 산도의 변화는 $\mathrm{pH}$ 변화와 마찬가지로 부패 현상 을 측정하는 지표로서 유용한 수단이며 미생물의 발육에 의해 생성되는 산을 측정함으로서 더욱 정확하게 부패 유무 를 판정할 수 있다. 저장온도 및 저장기간에 따른 볶음밥의 적정산도를 조사하여 Fig. 2 에 나타내었다. $-20^{\circ} \mathrm{C}$ 에 저장된 볶음밥의 적정산도는 저장 0 주째 $0.4 \%$ 이었고 저장 6 주에는 $0.4 \%$ 로 나타나 저장 중 거의 변화가 없는 것으로 관찰되었 다. 반면, $4^{\circ} \mathrm{C}$ 에서 저장된 볶음밥의 적정산도는 저장 0 주째 $0.48 \%$ 이었으나, 저장 2 주째에는 $2.8 \%$ 으로 급격히 증가하 였고 저장 6주째까지 2.7 3.1\% 수준으로 나타났다. 이는 $4{ }^{\circ} \mathrm{C}$ 에 저장된 볶음밥의 $\mathrm{pH}$ 가 저장 2 주째 급격히 감소하였 다가 이후 거의 변화가 없게 나타난 결과와 상반된 결과를 보인다. 일반적으로 $\mathrm{pH}$ 가 낮아질수록 적정산도는 증가하 는 경향을 보이는데 본 연구결과에서도 이와 같은 경향을 보였다. $25^{\circ} \mathrm{C}$ 에 저장된 볶음밥의 적정산도는 저장 0 주째 $0.48 \%$ 로 나타났으나, 이 후 저장 6 주째까지 $3.24 ~ 4.61 \%$ 수준으로 나타났으며, 실험온도구간 중 저장 기간 동안 가 장 높은 적정산도를 보였다.

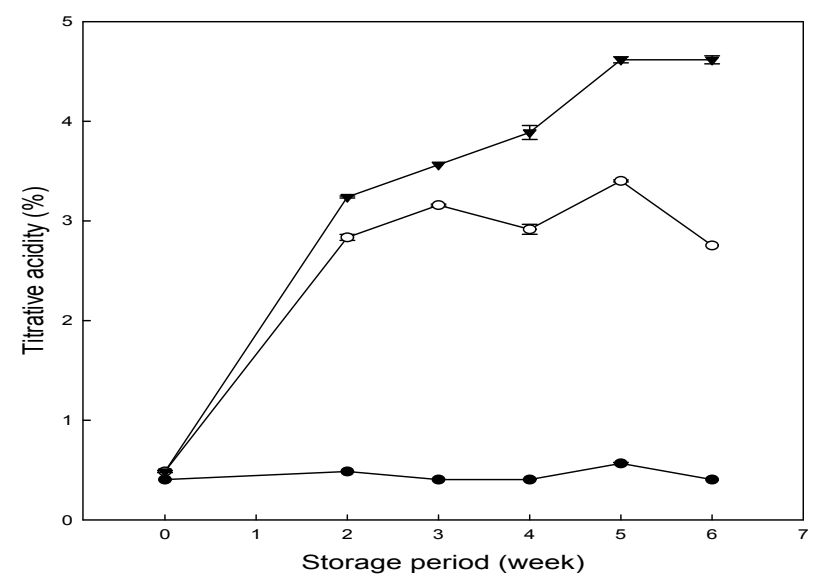

Fig. 2. Changes in the titrative acidity of fried rice depending on the storage period and temperature.

- $-20^{\circ} \mathrm{C} ; \quad 0,4^{\circ} \mathrm{C} ; \boldsymbol{\nabla}, 25^{\circ} \mathrm{C}$. Values are mean $\pm \mathrm{SD}(\mathrm{n}=5)$.
$\mathrm{TBA}$ 값

TBA 값은 일반적으로 식품유지의 산패도, 품질관리, 산 화에 대한 저항성 등을 측정하는 척도로서 이용되고 있다. Peroxide value(POV)는 산패가 높으면 값이 증가하다가 감 소하는 경향을 보이지만, TBA는 산패가 높으면 지속적으 로 증가하게 되어 유지의 산패도 경향을 판단할 수 있다. 꽃게풍미 볶음밥의 경우 볶음밥의 부원료로 사용된 유화소 스, 자숙농축액, 들기름 등이 저장온도와 저장기간 동안 어떻게 변화되며 식품의 품질에 어떠한 영향을 미치는지에 대해 조사할 필요가 있다. 이러한 측면에서 꽃게풍미 볶음 밥의 저장 중 유지의 산패도 변화를 관찰하기 위해 TBA 값을 측정하였고 유지산패 생성물인 malondialdehyde 함량 $(\mu \mathrm{g} / \mathrm{g})$ 으로 나타내었다. 저장온도 및 저장기간에 따른 볶음 밥의 malondialdehyde 함량을 조사하여 Fig. 3에 나타내었 다. $-20^{\circ} \mathrm{C}$ 에 저장된 볶음밥의 경우 저장 0 주째 $1.07 \mathrm{\mu g} / \mathrm{g}$ 이었 고, 저장 3 주째 $1.16 \mu \mathrm{g} / \mathrm{g}$ 으로 증가하였으며 이후 저장 6 주 까지 $1.25 ~ 1.39 \mu \mathrm{g} / \mathrm{g}$ 으로 나타나 저장 중 다소 증가하는 경향을 보였다. 반면, $4^{\circ} \mathrm{C}$ 에서 저장된 볶음밥의 저장 0 주째 malondialdehyde 함량은 $1.24 \mathrm{\mu g} / \mathrm{g}$ 이었으나, 저장 2 주째에 는 $1.30 \mu \mathrm{g} / \mathrm{g}$ 으로 약간 증가하였고, 저장 3 주째에는 1.43 $\mathrm{\mu g} / \mathrm{g}$, 저장 4 5주째에는 $1.62 \sim 1.61 \mathrm{\mu g} / \mathrm{g}$ 으로 증가하였으며 저장 6 주째에는 $1.98 \mathrm{\mu g} / \mathrm{g}$ 수준으로 나타나 볶음밥에 함유 된 유지의 산패가 저장초기에 비해 약간 진행된 것으로 사료된다. $25^{\circ} \mathrm{C}$ 에 저장된 볶음밥의 경우 저장 0 주째 malondialdehyde 함량 $1.24 \mu \mathrm{g} / \mathrm{g}$ 이었으나, 저장 2 주째에는 $2.5 \mu \mathrm{g} / \mathrm{g}$ 으로 나타났고, 이 후 저장 6주째까지 $3.3 ~ 4.2 \mu \mathrm{g} / \mathrm{g}$ 수준으로 나타나 처리구 중 저장기간 동안 가장 높은 malondialdehyde 함량을 보였다. Keskinel 등(19)의 연구에 서 TBA가의 변화는 $\mathrm{pH}$, 시료의 크기, 온도에 크게 영향을 받는다고 보고하였는데 일반적으로 저장기간이 경과할수 록 TBA가가 증가한다고(20) 보고하여 본 연구의 결과와 동일하게 나타났다. Kim 등(21)은 백미의 주지방산인 oleic

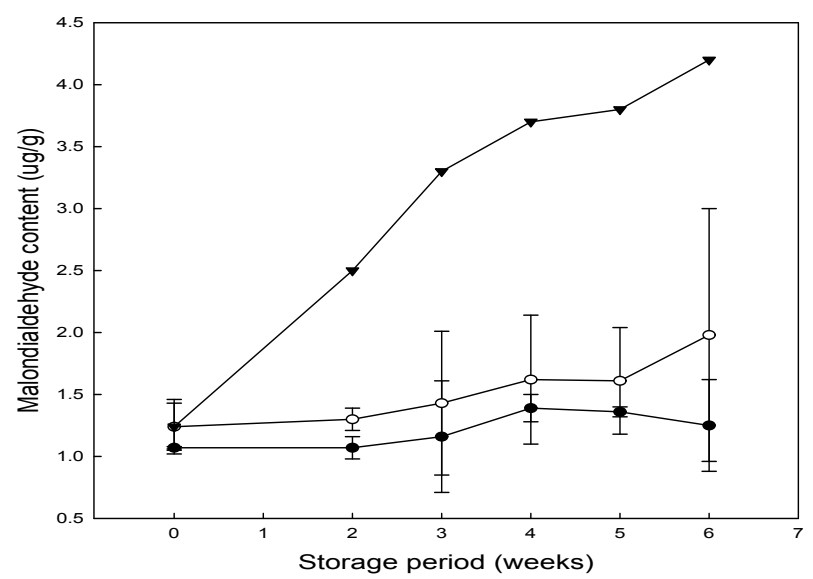

Fig. 3. Changes in the TBA value of fried rice depending on the storage period and temperature.

- $-20^{\circ} \mathrm{C} ; \quad \mathrm{O}, 4^{\circ} \mathrm{C} ; \boldsymbol{\nabla}, 25^{\circ} \mathrm{C}$. Values are mean $\pm \mathrm{SD}(\mathrm{n}=5)$. 
acid와 linolenic acid가 공기 중의 산소와 결합하여 가수분 해되고 유리지방산을 생성하게 되어 고유의 맛과 풍미를 떨어뜨리게 된다고 보고하였다. 본 연구에서도 볶음밥의 주지방산이 산소와 결합하여 산화됨으로써 볶음밥의 품질 을 저하시키는 원인으로 작용한 것으로 사료되었다.

\section{휘발성염기질소}

휘발성염기질소 함량은 단백질의 변패 정도를 측정하는 것으로 식품의 저장성 설정 지표로 사용된다. 저장온도 및 저장기간에 따른 볶음밥의 휘발성염기질소를 조사한 결과 는 Fig. 4 와 같다. $-20^{\circ} \mathrm{C}$ 에 저장된 볶음밥의 경우 저장 0 주째 휘발성염기질소량은 $26.60 \mathrm{mg} \%$ 이었고 저장 6주에는 28.14 $\mathrm{mg} \%$ 로 나타나 저장 중 거의 변화가 없는 것으로 관찰되었 다. 반면, $4^{\circ} \mathrm{C}$ 에서 저장된 볶음밥의 저장 0 주째 휘발성염기 질소량은 $27.30 \mathrm{mg} \%$ 이었으나, 저장 2주째에는 $50.44 \mathrm{mg} \%$ 로 급격히 증가하였고, 저장 6주째까지 53.74 65.15 mg\% 수준으로 나타나 볶음밥의 신선도가 많이 떨어진 것으로 사료되었다. $25^{\circ} \mathrm{C}$ 에 저장된 볶음밥의 경우 저장 0 주째 휘발 성염기질소량은 $27.70 \mathrm{mg} \%$ 이었으나, 저장 1 주째에는 $35.70 \mathrm{mg} \%$ 로 나타났고, 이 후 저장 6주째까지 53.19 68.00 $\mathrm{mg} \%$ 수준으로 나타나 처리구 중 저장 기간 동안 가장 높은 휘발성염기질소량을 보였다.

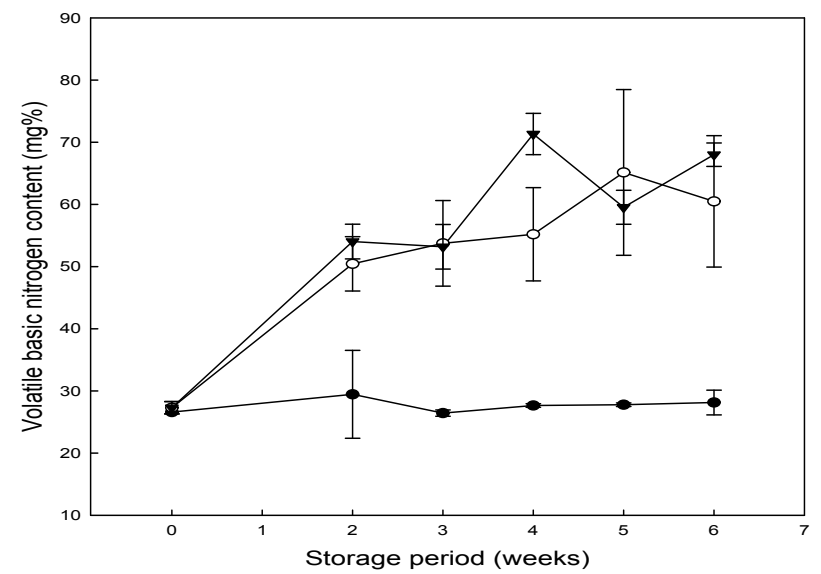

Fig. 4. Changes in the VBN value of fried rice depending on the storage period and temperature.

- $-20^{\circ} \mathrm{C} ; \mathrm{O}, 4^{\circ} \mathrm{C} ; \boldsymbol{\nabla}, 25^{\circ} \mathrm{C}$. Values are mean $\pm \mathrm{SD}(\mathrm{n}=5)$.

미생물 변화

저장온도 및 저장기간에 따른 볶음밥의 총균수의 변화를 조사한 결과는 $\mathrm{Fig}$. 5 와 같다. $-20^{\circ} \mathrm{C}$ 에 저장된 볶음밥의 경우 저장 0주째 $3.58 \log \mathrm{CFU} / \mathrm{g}$ 이었고 저장 6주째에는 $4.11 \mathrm{log}$ $\mathrm{CFU} / \mathrm{g}$ 으로 나타나 저장기간 동안 미생물변화는 거의 없는 것으로 관찰되었으며, 식품의 부패 기준 $(6.0 \log \mathrm{CFU} / \mathrm{g})$ 보 다 낮게 나타났다. 반면, $4^{\circ} \mathrm{C}$ 에서 저장된 볶음밥의 저장 0 주째 총균수는 $3.58 \log \mathrm{CFU} / \mathrm{g}$ 이었으나, 저장 2 주째에는 $8.04 \log \mathrm{CFU} / \mathrm{g}$ 으로 급격하게 증가하였고, 저장 3주째부터
6주째까지는 8.32 8.58 $\log \mathrm{CFU} / \mathrm{g}$ 으로 나타나 거의 변화가 없었다. 즉, $4{ }^{\circ} \mathrm{C}$ 에서 저장된 볶음밥은 저장 2 주째에 식품의 부패 기준 $(6.0 \log \mathrm{CFU} / \mathrm{g})$ 보다 높게 나타나 식품으로서의 품질을 잃은 것으로 사료되었다. $25^{\circ} \mathrm{C}$ 에 저장된 볶음밥의 경우 저장 0주째 총균수는 $3.58 \log \mathrm{CFU} / \mathrm{g}$ 이었으나, 저장 2주째에는 $8.54 \log \mathrm{CFU} / \mathrm{g}$ 으로 나타났으며 이 후 지속적으 로 감소하는 경향을 보였다. 이는 저장 2주째 이후부터 적정 산도의 지속적인 감소에 따라 낮은 $\mathrm{pH}$ 환경에서 미생물이 생육하기 어려워 나타난 것에 기인된 것으로 사료된다. 꽃 게 풍미 볶음밥의 일반세균수는 $-20^{\circ} \mathrm{C}$ 의 경우 저장기간 동 안 식품공전 기준인 $6 \log \mathrm{CFU} / \mathrm{g}$ 이하로 검출되었다. 반면, $4^{\circ} \mathrm{C}$ 와 $25^{\circ} \mathrm{C}$ 에서 저장된 볶음밥의 경우 저장 2주째에 $6 \mathrm{log}$ $\mathrm{CFU} / \mathrm{g}$ 이상이 검출되어 기준에 적합하지 않는 것으로 나타 났다.

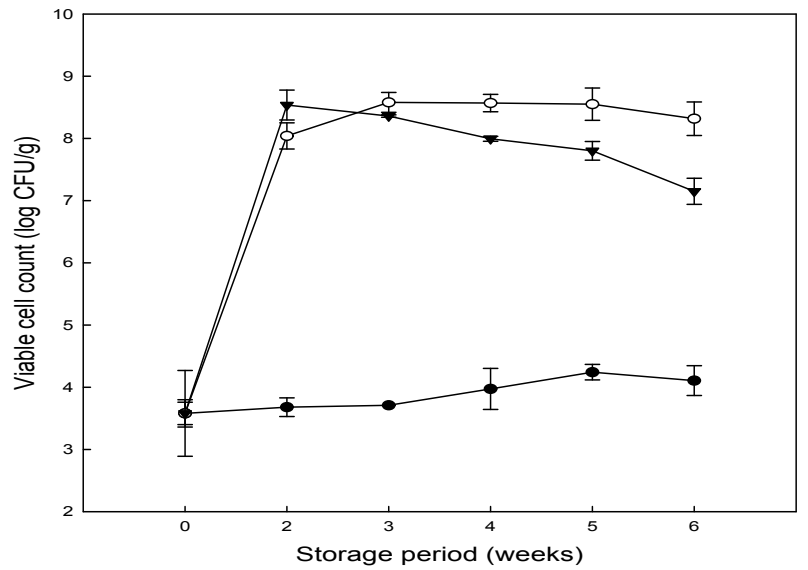

Fig. 5. Changes in the total plate counts of fried rice depending on the storage period and temperature.

- $-20^{\circ} \mathrm{C} ; \mathrm{O}, 4^{\circ} \mathrm{C} ; \boldsymbol{\nabla}, 25^{\circ} \mathrm{C}$. Values are mean $\pm \mathrm{SD}(\mathrm{n}=5)$.

관능적 기호도

저장온도 및 저장기간에 따른 볶음밥의 관능적 기호도를 조사한 결과는 Table 3 과 같다. 외관의 기호도는 $-20^{\circ} \mathrm{C}$ 에 저장된 볶음밥의 경우 거의 변화없이 7.0 7.8 수준을 보였 다. 반면 $4^{\circ} \mathrm{C}$ 에 저장된 볶음밥은 저장 2 주째에는 4.5 로 급격 히 감소하였고 이후 저장 6주째까지 1.9 2.5 수준의 평가를 받았다. $25^{\circ} \mathrm{C}$ 에 저장된 볶음밥은 저장 0 주째에는 높은 평가 를 받은 반면 저장 2주째 이후부터 1.1 2.5 수준의 평가를 받아 저장온도 및 저장기간 동안 가장 낮은 평가를 받았다. 색의 기호도는 $-20^{\circ} \mathrm{C}$ 에 저장된 볶음밥의 경우 저장초기 7.5 이었고 저장 6 주째에는 6.3으로 나타나 저장기간 동안 서서 히 낮은 평가를 받았다. 반면 $4^{\circ} \mathrm{C}$ 에 저장된 볶음밥은 저장 6 주째까지 $1.5 \sim 2.5$ 수준의 평가를 받았다. $25^{\circ} \mathrm{C}$ 의 경우 저장 2주째에는 1.5 이었으며 이 후 저장 6주째까지 1.0 1.5 수준 의 평가를 받아 저장온도 및 저장기간 동안 가장 낮은 평가 를 받았다. $25^{\circ} \mathrm{C}$ 에 저장된 볶음밥은 저장 1 주째에 이미 탁한 색을 나타내었다. 이는 미생물의 급격한 증가로 미생물에 
Table 3. Sensory evaluation of fried rice depending on the storage period and temperature

\begin{tabular}{|c|c|c|c|c|c|c|c|}
\hline \multirow{2}{*}{ Sensory characteristics } & \multirow{2}{*}{$\begin{array}{l}\text { Temp. } \\
\left({ }^{\circ} \mathrm{C}\right)\end{array}$} & \multicolumn{6}{|c|}{ Storage period (week) } \\
\hline & & 0 & 2 & 3 & 4 & 5 & 6 \\
\hline \multirow{3}{*}{ Appearance } & -20 & $7.5 \pm 0.7^{\text {al) }}$ & $7.8 \pm 0.4^{\mathrm{a}}$ & $7.5 \pm 0.0^{\mathrm{a}}$ & $7.3 \pm 0.4^{\mathrm{a}}$ & $7.1 \pm 0.1^{\mathrm{a}}$ & $7.0 \pm 0.2^{\mathrm{a}}$ \\
\hline & 4 & $7.5 \pm 0.7^{7^{22}}$ & $4.5 \pm 0.7^{b}$ & $2.5 \pm 0.7^{\mathfrak{c}}$ & $2.4 \pm 0.2^{\mathrm{c}}$ & $2.1 \pm 0.1^{\mathrm{c}}$ & $1.9 \pm 0.1^{c}$ \\
\hline & 25 & $7.0 \pm 1.4^{\mathrm{a}}$ & $2.5 \pm 0.7^{\mathrm{b}}$ & $2.5 \pm 0.7^{\mathrm{b}}$ & $2.3 \pm 1.1^{\mathrm{b}}$ & $2.1 \pm 0.8^{\mathrm{b}}$ & $1.1 \pm 0.1^{\mathrm{c}}$ \\
\hline \multirow{3}{*}{ Color } & -20 & $7.5 \pm 0.7^{\mathrm{a}}$ & $7.3 \pm 1.1^{\mathrm{a}}$ & $6.8 \pm 0.4^{\mathrm{a}}$ & $6.7 \pm 0.2^{\mathrm{a}}$ & $6.5 \pm 0.1^{\mathrm{a}}$ & $6.3 \pm 0.1^{\mathrm{a}}$ \\
\hline & 4 & $7.5 \pm 0.7^{\mathrm{a}}$ & $5.5 \pm 2.1^{\mathrm{a}}$ & $2.5 \pm 0.7^{b}$ & $2.2 \pm 0.3^{\mathrm{b}}$ & $2.0 \pm 0.0^{\mathrm{b}}$ & $1.5 \pm 0.0^{b}$ \\
\hline & 25 & $7.0 \pm 1.4^{\mathrm{a}}$ & $1.5 \pm 0.7^{\mathrm{b}}$ & $1.5 \pm 0.7^{b}$ & $1.3 \pm 0.4^{\mathrm{b}}$ & $1.1 \pm 0.1^{\mathrm{b}}$ & $1.0 \pm 0.0^{b}$ \\
\hline \multirow{3}{*}{ Flavor } & -20 & $8.0 \pm 1.4^{\mathrm{a}}$ & $7.8 \pm 0.4^{\mathrm{a}}$ & $7.5 \pm 0.0^{\mathrm{a}}$ & $7.5 \pm 0.0^{\mathrm{a}}$ & $7.3 \pm 0.3^{\mathrm{a}}$ & $6.9 \pm 0.1^{\mathrm{a}}$ \\
\hline & 4 & $8.0 \pm 0.7^{\mathrm{a}}$ & $4.5 \pm 0.7^{b}$ & $1.5 \pm 0.7^{b}$ & $1.1 \pm 0.1^{\mathrm{b}}$ & $1.0 \pm 0.0^{\mathrm{b}}$ & $1.0 \pm 0.0^{\mathrm{b}}$ \\
\hline & 25 & $7.5 \pm 0.7^{\mathrm{a}}$ & $1.0 \pm 0.0^{\mathrm{b}}$ & $1.0 \pm 0.0^{\mathrm{b}}$ & $1.0 \pm 0.0^{\mathrm{b}}$ & $1.0 \pm 0.0^{\mathrm{b}}$ & $1.0 \pm 0.0^{\mathrm{b}}$ \\
\hline \multirow{3}{*}{ Taste } & -20 & $7.8 \pm 0.4^{\mathrm{a}}$ & $7.3 \pm 0.4^{\mathrm{a}}$ & $7.3 \pm 0.4^{\mathrm{ab}}$ & $7.1 \pm 0.1^{\mathrm{ab}}$ & $6.9 \pm 0.1^{\mathrm{b}}$ & $6.8 \pm 0.0^{b}$ \\
\hline & 4 & $7.5 \pm 0.0$ & - & - & - & - & - \\
\hline & 25 & $7.5 \pm 0.7$ & - & - & - & - & - \\
\hline \multirow{3}{*}{ Texture } & -20 & $7.5 \pm 0.7^{\mathrm{a}}$ & $7.3 \pm 0.4^{\mathrm{a}}$ & $7.3 \pm 0.4^{\mathrm{a}}$ & $7.2 \pm 0.2^{\mathrm{a}}$ & $7.0 \pm 0.1^{\mathrm{a}}$ & $6.9 \pm 0.1^{\mathrm{a}}$ \\
\hline & 4 & $7.5 \pm 1.1$ & - & - & - & - & - \\
\hline & 25 & $7.2 \pm 1.4$ & - & - & - & - & - \\
\hline \multirow{3}{*}{ Overall preference } & -20 & $7.8 \pm 0.4^{\mathrm{a}}$ & $7.3 \pm 0.4^{\mathrm{ab}}$ & $7.3 \pm 0.4^{\mathrm{ab}}$ & $7.2 \pm 0.2^{\mathrm{ab}}$ & $7.0 \pm 0.1^{b}$ & $6.7 \pm 0.3^{b}$ \\
\hline & 4 & $7.8 \pm 0.0^{\mathrm{a}}$ & $4.0 \pm 0.0^{\mathrm{b}}$ & $2.0 \pm 0.0^{\mathrm{b}}$ & $1.9 \pm 0.1^{\mathrm{b}}$ & $1.7 \pm 0.1^{\mathrm{b}}$ & $1.3 \pm 0.4^{c}$ \\
\hline & 25 & $7.5 \pm 0.7^{\mathrm{a}}$ & $1.0 \pm 0.7^{\mathrm{b}}$ & $1.0 \pm 0.0^{\mathrm{b}}$ & $1.0 \pm 0.0^{\mathrm{b}}$ & $1.0 \pm 0.0^{\mathrm{b}}$ & $1.0 \pm 0.0^{b}$ \\
\hline
\end{tabular}

${ }^{1)}$ Values are mean \pm SD $(\mathrm{n}=5)$.

${ }^{2)}$ Means with different superscripts within a column indicate significantly differences at $\mathrm{p}<0.05$ by Duncan's test.

의해 생성된 부산물이 색의 기호도 저하에 영향을 미친 것으로 사료된다. 향의 기호도 변화는 $-20^{\circ} \mathrm{C}$ 에 저장된 볶음 밥의 경우 저장초기 8.0 이었고 저장 6주째에는 6.9으로 나 타나 저장기간 동안 가장 높은 평가를 받았다. 반면 $4{ }^{\circ} \mathrm{C}$ 에 저장된 볶음밥은 저장 2 주째에는 4.5 로 급격히 감소하였고 이후 저장 6주째까지 1.0 1.5 수준의 낮은 평가를 받았다. $25^{\circ} \mathrm{C}$ 의 경우 저장 6 주째까지 1.0 수준의 평가를 받아 저장온 도 및 저장기간 동안 가장 낮은 평가를 받았다. $25^{\circ} \mathrm{C}$ 에 저장 된 볶음밥은 저장 1 주째에 이미 꽃게풍미가 나지 않았고, 기름이 산패된 것 같은 향이 나타났으며 이러한 요인에 기인하여 저장기간 동안 가장 낮은 향의 기호도 평가를 받은 것으로 사료된다. 맛의 기호도는 $-20^{\circ} \mathrm{C}$ 에 저장된 볶음 밥의 경우 저장초기 7.8 이었고 저장 6주째에는 6.8으로 나 타나 실험군중 가장 높은 평가를 받았다. 반면, $4,25^{\circ} \mathrm{C}$ 에 저장된 볶음밥은 저장 2주째부터 식용을 할 수 없을 정도의 이취가 나타나 맛 평가를 수행할 수 없었다. 이는 미생물의 성장이 저장 2주째부터 식품의 부패기준인 $6.0 \mathrm{log} \mathrm{CFU} / \mathrm{g}$ 을 초과한데다 볶음밥에 함유된 유지의 산패에 의해 TBA 값 이 저장 2주째부터 급격하게 증가하여 볶음밥의 품질이 저하되었기 때문인 것으로 생각되어진다. 식품의 조직감은 식품의 맛을 결정하는 요소로써, 밥의 질감을 결정하는데 있어서 가장 중요한 지표로 사용되는 인자이다(22). 조직감
의 기호도 변화는 $-20^{\circ} \mathrm{C}$ 에 저장된 볶음밥의 경우 저장초기 7.5 이었고 저장 6 주째에는 6.9로 나타나 저장기간 동안 거 의 일정하게 높은 수준의 평가를 받았다. 반면 4 및 $25^{\circ} \mathrm{C}$ 에 저장된 볶음밥은 저장 2 주째부터 식용할 수 없을 정도로 품질이 저하되어 볶음밥의 조직감 기호도를 측정할 수 없었 다. 종합적 기호도 변화는 $-20^{\circ} \mathrm{C}$ 에 저장된 볶음밥의 경우 저장초기 7.8 이었고 저장 6주째에는 6.7로 나타나 저장기간 동안 처리구 중 가장 높은 평가를 받았다. 반면 $4^{\circ} \mathrm{C}$ 에 저장 된 볶음밥은 저장 2 주째에는 4.0 으로 급격히 감소하였고 이후 저장 6주째까지 1.3 2.0 수준으로 낮은 평가를 받았다. $25^{\circ} \mathrm{C}$ 의 경우 저장 6 주째까지 1.0 수준의 평가를 받아 저장온 도 및 저장기간 동안 가장 낮은 평가를 받았다. 4 및 $25^{\circ} \mathrm{C}$ 에 저장된 볶음밥의 종합적 기호도가 가장 낮은 평가를 받은 것은 외관, 맛, 향, 조직감 등 평가시 가장 낮은 기호도를 보인 것에 기인한 것으로 사료된다.

\section{유통기한의 예측}

저장온도 및 저장기간에 따른 볶음밥의 유통기한을 예측 하여 Table 4에 나타내었다. 볶음밥의 유통기한을 설정하기 위해 식품공전에서 미생물에 의한 식품의 품질기준에 해당 하는 부패기준인 최대허용 미생물수 $6.0 \log \mathrm{CFU} / \mathrm{g}$ 을 기준 으로 안전계수 $(0.8)$ 를 사용하여 나타내었다. $-20^{\circ} \mathrm{C}$ 에 저장 
된 볶음밥의 미생물 변화를 토대로 1 차 회귀방정식을 도출 하였고 이 방정식에 의거하여 산출된 볶음밥의 유통기한은 18.6 주 이었으며 안전계수를 적용할 경우 14.9 주 인 것으로 예측되었다. $4^{\circ} \mathrm{C}$ 에 저장된 볶음밥의 미생물 변화를 토대로 1 차 회귀방정식을 도출하였고, 이 방정식에 의거하여 산출 된 볶음밥의 유통기한은 0.5 주 이었으며, 안전계수를 적용 할 경우 0.5 주 인 것으로 예측되었다. 시판 볶음밥의 유통기 한은 제조사에 따라 다소 차이가 있었지만(data not shown), 평균적으로 7 9개월(28 36주)인 것으로 조사되었는데, 본 연구에서의 볶음밥은 미생물을 기준으로 조사한 결과 -2 $0^{\circ} \mathrm{C}$ 냉동 보관시 4.6 개월(18.6주)인 것으로 나타나 시판 볶 음밥에 비해 짧은 것으로 나타났다. 이는 꽃게풍미 볶음밥 제조시 최종적으로 자외선살균을 하지 않았고, 부원료로 사용된 유화소스, 꽃게자숙농축액 등의 지방성분에 의해 냉동보관중이라 하더라도 품질저하에 영향을 미쳤기 때문 에 시판 볶음밥에 비해 예측되는 유통기한이 짧게 나타난 것으로 사료되었다.

Table 4. Estimation of shelf-life based on the regression equation of viable cell count during storage at -20 and $4^{\circ} \mathrm{C}$

\begin{tabular}{cccc}
\hline $\begin{array}{c}\text { Storage } \\
\text { temp. }\left({ }^{\circ} \mathrm{C}\right)\end{array}$ & Regression equation & $\mathrm{r}^{2}$ & $\begin{array}{c}\text { Estimated shelf-life } \\
(\text { week })^{1)}\end{array}$ \\
\hline-20 & $\mathrm{y}=0.1311 \mathrm{x}+3.5545$ & 0.8569 & 14.9 \\
4 & $\mathrm{y}=0.7763 \mathrm{x}+5.6087$ & 0.5468 & 0.4 \\
\hline
\end{tabular}

${ }^{1)}$ Calculated period was calculated by regression equation at $6 \log \mathrm{CFU} / \mathrm{g}$ of aerobic plate counts under -20 and $4^{\circ} \mathrm{C}$ storage. Estimated shelf life=calculated shelf life $\times$ safety factor $(0.8)$.

\section{요 약}

꽃게 조미소재, 야채, 천연조미료 등을 활용하면서, 편의 성을 부여하기 위하여 꽃게풍미 볶음밥을 제조하였다. 꽃 게풍미 볶음밥의 저장 중 품질변화를 조사하기 위해 -20 , $4,25^{\circ} \mathrm{C}$ 에서 6 주 동안 저장하면서 $\mathrm{pH}$, 산도, 총균수, $\mathrm{TBA}$, $\mathrm{VBN}$, 관능적 기호도를 조사하였으며, 총균수 결과를 활용 하여 볶음밥의 유통 기한을 예측하였다. $\mathrm{pH}$ 변화를 조사한 결과, $-20^{\circ} \mathrm{C}$ 에 저장된 볶음밥의 경우 저장 0 주째 $\mathrm{pH}$ 는 7.74 이었고 저장 6주에는 $\mathrm{pH}$ 7.76으로 나타나 저장 중 변화가 거의 없는 것으로 나타났다. 적정산도를 조사한 결과, $-20^{\circ} \mathrm{C}$ 에 저장된 볶음밥의 경우 저장 0 주째에 $0.4 \%$ 이었고 저장 6 주에는 $0.4 \%$ 로 거의 변화가 없었다. 반면, $4{ }^{\circ} \mathrm{C}$ 와 $25^{\circ} \mathrm{C}$ 의 저장 6 주에는 각각 $2.7 \%, 4.6 \%$ 의 수준으로 나타났다. $\mathrm{TBA}$ 값을 측정한 결과, $-20^{\circ} \mathrm{C}$ 에 저장한 볶음밥의 경우 저장 0 주째 $1.07 \mu \mathrm{g} / \mathrm{g}$ 이었고, 저장 6주까지 $1.39 \mu \mathrm{g} / \mathrm{g}$ 으로 나타나 저장 중 다소 증가하는 경향을 보였다. 휘발성염기질소를 조사한 결과, $-20^{\circ} \mathrm{C}$ 에 저장된 볶음밥의 경우 저장 0 주째에 $26.60 \mathrm{mg} \%$ 이었고, 저장 6주에는 $28.14 \mathrm{mg} \%$ 로 나타나 신선
도가 유지되는 것으로 사료되었다. $4^{\circ} \mathrm{C}$ 와 $25^{\circ} \mathrm{C}$ 의 저장 6 주 에는 각각 $65.15 \mathrm{mg} \%, 68.00 \mathrm{mg} \%$ 수준으로 나타났다. 총균 수의 변화를 조사한 결과, $-20^{\circ} \mathrm{C}$ 저장된 볶음밥의 경우 저장 0주째 $3.58 \log \mathrm{CFU} / \mathrm{g}$ 이었고 저장 6주째에는 $4.11 \log$ $\mathrm{CFU} / \mathrm{g}$ 으로 나타나 미생물변화는 안정적인 것으로 관찰되 었다. 관능적 기호도를 조사한 결과, $-20^{\circ} \mathrm{C}$ 에 저장된 볶음밥 의 경우 종합적 기호도의 변화를 보았을 때, 저장초기 7.8 이 었고 6주째에는 6.7으로 나타나 저장 기간 동안 처리구 중 가장 높은 평가를 받았다. $25^{\circ} \mathrm{C}$ 의 경우 저장초기 $7.5^{\circ}$ 이었으 나, 저장 6주째 1.0 수준의 평가를 받아 저장온도 및 저장기 간 동안 가장 낮은 평가를 받았다. 미생물 결과를 토대로 볶음밥의 유통기한을 예측한 결과, $-20^{\circ} \mathrm{C}$ 에 저장할 경우 14.9 주, $4^{\circ} \mathrm{C}$ 에서 저장할 경우 0.4 주 인 것으로 각각 조사되었 다. 이상의 결과를 종합해 볼 때, 꽃게풍미 볶음밥은 $-20^{\circ} \mathrm{C}$ 에 서 저장하는 것이 미생물학적 및 관능적인 측면에서 저장성 이 좋을 것으로 사료되었고, 편의식품화로서의 이용 가능 성이 있을 것으로 생각되었다.

\section{감사의 글}

본 연구는 2013년 인천수산자원연구소의 지역연고육성 사업(G02046)의 지원을 받아 수행된 연구결과의 일부이며, 이에 감사드립니다.

\section{References}

1. Lee BC, Eun JB (2008) Rice processing in food industry. Food Ind Nutr, 13, 1-8

2. Jun HK (2007) Changes in eating habits and outlook. Paper presented at Center for Food, Agricultural and Rural Policy, July 20, Seoul, Korea

3. Lee FZ, Lee JC, Jung DS, Yung HC, Eun JB (2001) Chemical composition of blue crabs preserved in soy sauce. Korean J Food Sci Technol, 33, 714-719

4. Gilles R (1970) Osmoregulation in the stenohaline crab libinia emarginata. Archs Int Physiol Biochem, 78, 91-99

5. Giddings GG, Hill LH (1975) Processing effects on the lipid fractions and principal fatty acids of blue crab (Callinecetes sapidus) muscle. J Food Sci, 40, 1127-1129

6. Hiltz DF, Bishop LJ (1975) Postmortem glycolytic and nucleotide degradation changes in muscle of the atlantic queen crab (Chionoecetes opilio) upon iced storage of unfrozen and of thawed meat, and upon cooking. Comp Biochem Physiol, 52, 453-458

7. Take T, Yoshimura Y, Otsuka H (1967) Studies on the 
tasty substances in various foodstuffs. On the tasty substances of edible crab. J Home Econ Jpn, 18, 209-212

8. Konosu S, Yamaguchi K, Hayashi T (1978) Studies on flavor components in boiled crabs. I. Amino acids and related components in the extracts. Bull Jpn Soc Scien Fish, 44, 505-510

9. Hayashi T, Yamaguchi K, Konosu S (1978) Studies on flavor components in boiled crabs. П. Nucleotides and organic bases in extracts. Bull Jpn Soc Sci Fish, 44, $1357-1362$

10. Hayashi T, Yamaguchi K, Konosu S (1981) Sensory analysis of taste-active components in the extract of boiled snow crab meat. J Food Sci, 46, 479-483

11. Hayashi T, Ren H, Akiba T, Endo H, Watanabe E (1993) Extractive components of unutilized small crabs and their sensory evaluation as seasonings. Bull Jpn Soc Sci Fish, $59,865-873$

12. AOAC (2006) Official Methods of Analysis. 15th ed, Association of Official Analytical Chemists. Washington DC, p 210-219

13. Doughty HW (1924) Mohr's method for the determination of silver and halogens in other than neutral solutions.

J Am Chem Soc, 46, 2707-2709

14. Yang SC, Lee IA, Sun JH, Kim DE, Kang WS, Chung HS, Shin MS, Ko SH (2010) Development of well- reconstituted instantized thin rice gruel. Food Eng Prog, $14,54-59$

15. Witte VC, Krause GF, Bailey ME (1970) New extraction method for determining 2-thiobarbituric acid values of pork and beef during storage. J Food Sci, 35, 582-585

16. Collins CH, Lyne PM (1985) Microbiological methods. 5th ed. Butterworth \& Co. Ltd., Boston. p 73, 130-133

17. Kim KM, Park HY, Jin HJ, Kim GC, Kim JS (2013) Studies on the nutrient contents of main dishes depending on the amount of cooking. Food Eng Prog, 17, 369-376

18. Bhullar SJ, Dhillon SB, Randhawa SJ (1985) Effect of wrappers on the storage of kinnow mandarin. J Res Punjab Agric Univ, 22, 663

19. Keskinel A, Ayres JC, Hnyer HE (1964) Determination of oxidative changes of meats by the 2-thiobarbituric acid method. J Food Tech, 18, 223-228

20. Witte VC, Krause GF, Baile ME (1970) A new extraction method for determining 2-thiobarbituric acid values of pork and beef during storage. J Food Sci, 35, 352-358

21. Kim OW, Kim H, Lim TG (2004) Cooling and storage characteristics of milled rice by different cooling storage methods. Korean J Food Preserv, 11, 448-454

22. Kim SR, Ahn JY, Lee HY, Ha TY (2004) Various properities and phenolic acid contents of rices and rice brans with different milling fractions. Korean $\mathbf{J}$ Food Sci Technol, 36, 930-936 